\title{
Servant Leadership Impact on Organizational Performance: The Mediating Role of Employee Engagement
}

\author{
Rawan Alafeshat (Corresponding Author), \\ Northern Cyprus, Gazi Magusa, Mersin on Turkey \\ E-mail: Rawan.alafeshat@emu.edu.tr; rawanalafeshat708@gmail.com
}

Farida Aboud, Northern Cyprus, Gazi Magusa, Mersin on Turkey, E-mail: aboudfarida18@gmail.com

Received: Jan. 22, 2019 Accepted: Feb. 18, 2019 Online published: Jul. 9, 2019 doi:10.5296/ijhrs.v9i3.15047ＵRL: https://doi.org/10.5296/ijhrs.v9i3.15047

\begin{abstract}
The current study, which purposed to examine the mediating role of Employee Engagement (EE) in the relationship of Servant Leadership (SL) with the Organizational Performance (OP), was carried out in Jordan. The researchers distributed a questionnaire to 277 participants working in the private airline sector. The study's findings showed that SL was positively linked with Employee Satisfaction (ES) and Employee Retention (ER) as indicators for OP. Finally; the findings indicated that EE partially mediates the relationships of SL with employee satisfaction and employee retention. The current research is the first empirical study of the airline sector in Jordan. It is also the first to focus on EE as a mediator of the effect of SL and employee retention using Structural Equation Modeling (SEM) for analyzing the data collected from employees working in the airline sector.
\end{abstract}

Keywords: servant leadership, employee engagement, employee satisfaction, employee retention

\section{Introduction}

Leaders are considered to be a part of the organization, and they are in charge of different missions such as planning, organizing, evaluating, motivating, etc. (Hao, \& Yazdanifard, 2015). Also, they are qualified with different types of competence and work experience to 
guide the workforce towards achieving the objectives of the organization(İkinci, 2014). Due to the importance of existence of the leaders in any business, authors continued highlighting this aspect in various fields. As expected, different changes happened because of the rapid developments in the companies sector. For that reason, researchers started searching for a new style of leaders who are prepared to guide the organization towards the success. Greenleaf (1977) was one of them; he was the founder of the servant leadership aspect (as cited in McCann et al., 2014). The focus of attention is serving with positive emotions and aspiration to direct the organization with the aim of success (Greenleaf, 1977, p.27; as cited in Spears, 2010).

Tourism in Jordan is considered as a vital business for the country, Therefore, the airline sector (whether private or non-private) hires a huge number of workface and leaderships to achieve the aims of the organization. A lot of studies confirmed the significant impact of SL on increasing ES (Rozika et al., 2018), ER (Kashyap \& Rangnekar, 2014), EE (Kaur, 2018), and OP (Baykal et al., 2018). However, the focus on examining the link between SL and EE in the service sector is inadequate (Carter and Baghurst, 2014). Besides, no practical research has measured the mediating role of EE in the relationships of SL with ES and ER.

The current study makes essential contributions based on the precepts of Ability, Motivation, and Opportunities theory (AMO). It utilizes EE as a mediator between SL and the two indicators of an OP (i.e. ES and ER). Moreover, EE via the application of AMO theory is an essential means for any organization to raise its performance.

The current research has different purposes; it studies the relationship between SL and OP. In addition, it examines the mediating role of EE between the relationship of SL and OP.

\section{Theoretical Background, Hypotheses and Research Model}

The current part briefly highlighted particular studies related to SL and OP, SL and ES, SL and ER, SL and EE, EE and OP, and EE as a mediator. Besides, the hypothesis and the research model were provided in this section.

\subsection{Servant Leadership and Organizational Performance}

The concept of OP can be defined as achieving particular purposes of the organization through varied types of collaborative activities, individual and managers efforts (Lisbijanto \& Budiyanto, 2014). Many years ago, the scholars in the business and management field highlighted leadership perspective as a criterium for mastering success in that sector. So, in the light of the rapid changes, the given perspective has developed to become the SL for fulfilling new missions in that given fields. Greenleaf (1977) was the founder of this aspect (as cited in McCann et al., 2014), and defined it, as "the servant-leader is servant first It begins with the natural feeling that one wants to serve. Then conscious choice brings one to aspire to lead" (Greenleaf, 1977, p.27; as cited in Spears, 2010).

The recent literature SL plays remarkable roles in increasing the level of OP (Olesia et al., 2013). Besides, it has a significant impact on the OP; for instance, Jones (2012) found the positive relationship between SL and OP in that SL contributed to increasing the OP. Further, 
Bass (2000) suggested the significant effect of SL on the organization due to its positive efforts on the employees. Similar to Baykal et al. (2018) and Peterson et al. (2012), both of the authors ensured the considerable and the significant emphasis of SL on improving the outcome of the company.

On the other hand, the relationship between SL and OP was considered negative. For example, in a conducted research by De Waal and Sivro (2012), the authors indicated the insignificant relationship between SL and OP. In other words, practicing SL did not positively impact the performance of the organization (Lisbijanto\& Budiyanto, 2014).

\subsection{Servant Leadership and Employee Satisfaction}

Since the aspect of SL has confirmed its positivity in improving the performance of the company, scholars in varied domains were interested in studying the mentioned concept from different points of view such as its effect on the ES. Phillips and Gully (2012) (as cited in McCann et al., 2014) defined ES as a great degree of positive attitudes, perceptions and real expectations of the employees toward the company where they work. Additionally, it directs the positive emotions of the individual toward the job (Sepahvand et al., 2015). To state this matter differently, when the employees have a strong feeling and positive emotions to achieve the goals of the company, it means that they have a sense of satisfaction towards what they do. These feelings can be created through the practicing of SL at that organization. For this reason, SL focuses on the employees for reaching a successful company.

From that perspective, enormous studies directed to examine the influence of SL on the degree of satisfaction among employees. Some revealed the positive impact of SL on increasing the level of satisfaction. For example, a study conducted by Sepahvand et al. (2015) and Rozika et al. (2018) indicated that SL significantly influences ES. McNeff and Irving (2017) also confirmed that ES was increased through the existence of SL at the company. Through encouraging the employees and developing their skills by SL, it contributed to constructing a sense of job satisfaction in the firm (Kaur, 2018). Moreover, a promising finding was produced in a work by Tischler et al. (2016) which showed that the relationship between SL and job satisfaction was significance. On the basis of these findings, the following hypothesis is proposed:

H1a: SL has positive impacts on ES.

\subsection{Servant Leadership and Employee Retention}

During the rapid changes and the developments in the domain of business and human resources, the organization might face varied challenges; ER is considered one of them (Das $\&$ Baruah, 2013). It is defined as the procedure of maintaining the employees work at that firm lasting for a large amount of time (Aguenza \& Som, 2012)through encouraging and providing supportive activities for the members till accomplishing the task at the company (Das \& Baruah, 2013). As mentioned previously, the link between SL and job satisfaction is seen to be considerable, which might increase the opportunity for the employees remaining at the firm. 
At the same vein, there were evidences approved the positive SL contribution of keeping the employees work at the organization. For instance, in a study by Le $\mathrm{Ng}$ et al. (2016), SL was found to have a role in decreasing the job quit among Hajjaj (2014) confirmed that SL and ER were positively related. Further, Kashyap and Rangnekar (2014) found that the retaining of employees was positively related to practicing of SL. Furthermore, Brohi et al. (2018) showed that the employees' intention to stay and work at a company was affected by the aspect of SL. In the light of the given results, the current hypothesis is proposed:

H1b: SL has significant effects on ER.

\subsection{Servant Leadership and Employee Engagement}

Many scholars studied EE for different reasons; for example, it could construct positive feelings between the members toward the missions of the organization (Sendawula et al., 2018). Also, the workers' engagement in attaining the purposes and the tasks of the company is considered as a key factor in reaching varied levels of the success (Young et al., 2018). Therefore, the researches were carried out to explore what aspects or conditions could affect the process of engaging among the employees. Some showed that the type of leaderships such as SL could contribute to increasing the opportunity of job engaging at the company (Coetzer et al., 2017). Kaur (2018) confirmed the positive effect of SL on EE. At the same vein, Coetzer et al. (2017) approved the considerable link between SL and EE. This finding was comparable to the study by Coetzer et al. (2017). Also, a further work by Hunter et al. (2013) revealed that the organization practicing SL contributed to increasing the engagement of the workface at the work. Besides, SL plays a role in creating positive feelings and increasing a job engagement between the employees (De Clercq et al., 2014). Considering the previous findings the current hypothesis is proposed:

H2: SL has a positive effect on EE.

\subsection{Employee Engagements and Organizational Performance}

Throughout the literature, the perspective of EE was shown to be one of the factors that might impact the performance of the firm. According Sendawula et al. (2018), EE can be described as positive feelings among the members toward accomplishing the missions of the organization. Besides, it is considered as a significant component in developing OP and achieving its task (Kazimoto, 2016). Also, EE plays a remarkable part in reaching the favorable results for that company such as the financial outcome (Devi, 2017).

This perspective can be grown through the collaboration between the organization and the workforce (Ongel, 2014). As it was asserted in the study of Albrecht (2012), there is a role for the company in encouraging and engaging the employees to develop its performance. In turn, this could lead to obtaining great profits and advantages for the company (Kazimoto, 2016). From these points of view, the scholars confirmed the significant link between EE and OP (Devi, 2017; Myilswamy \& Gayatri, 2014). An additional study showed that EE positively impacts the outcome of the company (Pillay \& Singh, 2018). Bery et al. (2015) clarified that when the company focuses on engaging the employees in achieving its objectives, it gives enhances its performance. Therefore, the company should provide motivating forces for the 
members to retain them with a high degree of satisfaction (Aguenza, \& Som, 2012)through using varied techniques to support their engagement process and obtain a successful outcome for the organization (Pillay \& Singh, 2018). Consequently, building on the given findings, the following hypothesis is proposed:

H3. EE positively influence (a) ER and (b) ES.

\subsection{Employee Engagement as Mediator}

As previously mentioned, EE plays a significant role in improving the OP. However, some studies stated that it could play a mediating role in multiple relationships. For example, Schaufeli and Salanova (2008) reported that EE fully mediates the effect of job resources on proactive behavior. Similarly, Yalabik et al. (2013) showed that EE plays a mediating role in the relationship between job satisfaction and employee performance in the sector of Banks in the UK. Moreover, Karatepe and Aga (2016) found that EE fully mediates the relationships of organizational mission achievement and perceived organizational support with job performance among frontline employees in banks in Northern Cyprus.

Empirically speaking, De Clercq et al. (2014) found a significant impact of SL on EE in an information technology organization in Ukraine, and Karatepe and Talebzadeh (2016) showed that SL played a vital role in enhancing EE in an airline company in Iran. However, there is a shortage of studies focusing on the link between SL and EE in the service sector (Carter and Baghurst, 2014). In addition, studies have revealed that SL significantly influences the individual performance levels. For example, Van Dierendonck and Nuijten (2011) measured the effects of SL on ES in the Netherlands and the UK. In addition, Wong et al. (2007) showed that SL is positively associated with ER. However, no conducted research has measured the mediating role of EE in the relationships of SL with ES and ER, which leads us to the following hypotheses:

H4: EE mediates the impacts of SL on (a) ER and (b) ES.

\subsection{Conceptual Research Model}

The conceptual model of the current study as illustrated in Diagram 1 explains the following proposed hypothesis. It supposed that the practices of HPWS to directly linked to EE. At the same time, the model shows that EE improves both ES and ER as indicators for OP. Additionally; it suggests that EE mediates the effect of HPWS practices on both ES and ER.. 


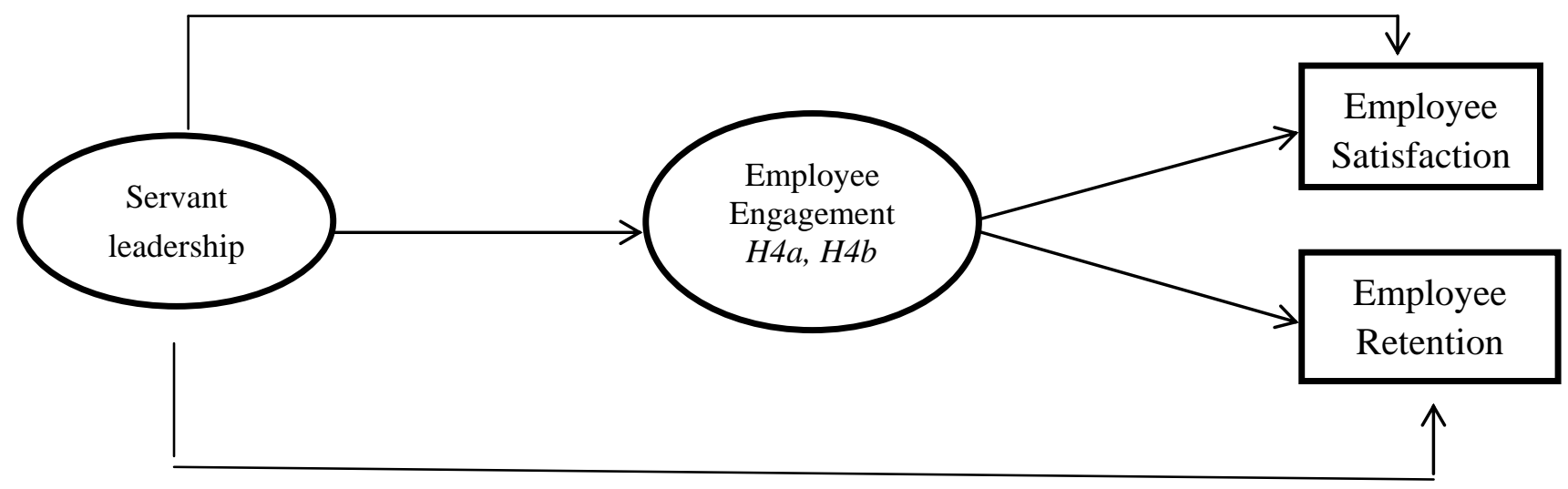

Figure 1. Conceptual Research Model

\section{Methodology}

\subsection{Samples and Procedure}

The current research was conducted in the private sector of airline companies in Jordan. Specific information about the data was gained from Jordan Civil Aviation Organization. The number of the sample was 300 employees working in the private airline sector during the two-month period of January and February 2018. This study selected the participants on the basis of judgmental sampling technique, which focuses on selecting the representative respondents based on particular standards (Karatepe, 2013). Varied types of employees with full-time positions at the private sector of airline were the main focus criteria of this study. Table 1 presents the subjects' profile; the number of male respondents was 168, while the female was 109. The age of participants ranged between 27 and over 48. Also, the participants were divided into three levels of education: four-year, two-year College, and graduate. In regards to their position, the participants were mangers, assistant managers, and employees while their type of job was check-in, transit check-in, baggage services, and other jobs (see Table 1 for subjects' profile).

The questionnaire was distributed to 300 employees, and 277 responses were valid while 23 were invalid. The response rate was $92 \%$.

\subsection{Measurement}

This study employed several items to measure the study variables. For instance, to measure the SL, five items were adopted from Otero-Neira et al. (2016). Three indicators, namely vigor, deduction, and absorption, measured EE using fifteen items were adapted from Schaufeli et al. (2006). Furthermore, the study used seven items from Barakat et al. (2016) to examine ES. Eight items adapted from Kundu et al. (2017) were employed to measure ER.

The responses to items related to SL, ES and ER were rated on a 5-point scale ranging from strongly agree (5) to strongly disagree (1). EE items were measured using a 7-point frequency rating ranging from always (7) to never (1). The questionnaire was firstly translated from the English language into Arabic; secondly it was translated into English by two professional English and Arabic translators to ensure equivalent meaning. 
Table 1. Subjects' Profile

\begin{tabular}{l|l|l}
\hline Construct & Frequency & Parentage \% \\
\hline Gender & & \\
\hline Male & 168 & 60.6 \\
\hline Female & 109 & 39.4 \\
\hline Age & & \\
\hline $18-27$ & 95 & 34.3 \\
\hline $28-37$ & 116 & 41.9 \\
\hline $38-47$ & 53 & 19.1 \\
\hline 47 -above & 13 & 4.7 \\
\hline Education level & & \\
\hline Two-year college & 105 & 37.9 \\
\hline Four-year & 105 & 53.8 \\
\hline Graduate & 23 & 8.3 \\
\hline Position of the job & & \\
\hline Manager & 19 & 6.9 \\
\hline Assistant & 49 & 17.7 \\
\hline Employee & 109 & 75.4 \\
\hline Type of the job & & \\
\hline Check-in & 80 & 28.9 \\
\hline Transit check-in & 45 & 16.2 \\
\hline Baggage service & 43 & 15.5 \\
\hline Other & 109 & 39.4 \\
\hline
\end{tabular}

\subsection{Analysis Strategy}

The hypotheses were tested based on the Structural Equation Model (SEM). Besides, the model fit was measured through employing varied fit indicators. According to (Hair et al., $2010)$, in the chi-square $\left(\chi^{2}\right)$ test, the chi-square to degrees of freedom ratio $\left(\chi^{2} / d f\right)$ must be less than three. The comparative fit index (CFI) should be greater than 0.90 (Kline, 2015), and the root mean square error of approximation (RMSEA) and standardized root mean square residual (SRMR) should be less than 0.08 (Hair et al., 2010). Confirmatory factor analysis (CFA) was employed to measure convergent, discriminant validity and composite reliability. In addition, Cronbach's alpha was measured to confirm the reliability of all factors and support their validity (Nunnally and Bernstein, 1994).

\section{Results}

\subsection{Factor Validity}

The results of the exploratory factor analysis (EFA) for the loading factors, Cronbach's alpha, average variance extracted (AVE), and composite reliability (CR) were illustrated in Table 2. Based on EFA findings, three items from EE, and one item from ES were deleted because of 


\section{Macrothink}

cross-loading factors.

The loading factors of the items ranged between 0.60 and 0.90 . Thus, all loadings were 0.60 or greater, indicating convergent validity (Hair et al., 2010; Fornell and Larcker, 1981). In addition, the reliability and the internal consistency of the statements were tested via Cronbach's alpha. Table 3 shows the values of Cronbach's alpha for each factor, in that the entire values were greater than 0.07 , providing evidence of reliability (Fornell and Larcker, 1981).

The AVE values for SL, ES, ER, and EE were 0.64, 0.53, 0.53, and 0.54 respectively. In support of discriminant validity, the AVE of each factor was more than the shared variance between factors (Hair et al., 2010). For example, the square of the link between SL and ER was >0.50. Moreover, the CR of each factor was greater than 0.60 (Fornell and Larcker, 1981).

Table 2. Results of Validity and Reliability Test

\begin{tabular}{l|l|l|l|l}
\hline Scale items & loading & Alpha & AVE & CR \\
\hline $\begin{array}{l}\text { Servant } \\
\text { Leadership }\end{array}$ & & .92 & .64 & .94 \\
\hline Item1 & .81 & & & \\
\hline Item2 & .80 & & & \\
\hline Ite33 & .90 & & & \\
\hline Item4 & .82 & & & \\
\hline Item5 & .74 & .71 & .53 & .94 \\
\hline Employee & & & & \\
Retention & .73 & & & \\
\hline Item6 & .62 & & & \\
\hline Item7 & .80 & & & \\
\hline Item8 & .70 & .80 & & \\
\hline Item9 & .80 & & & \\
\hline Item10 & .70 & & & \\
\hline Item11 & .80 & & & \\
\hline Item12 & .80 & & & \\
\hline Item13 & .80 & & & \\
\hline Employee & & & & \\
\hline Satisfaction & & & & \\
\hline Item14 & .54 & & & \\
\hline Item15 & & & \\
\hline Item16 & & & & \\
\hline Item17 & & & \\
\hline Item18 & & & \\
\hline Item19 & & & \\
\hline
\end{tabular}






\subsection{Correlation Results}

The means, standard deviations, and correlations for SL, EE, ER, and ES were reported in Table 3. The results show that SL was positively related to ER $(r=0.503, p<0.001)$ and ES $(r=0.538, p<0.05)$. Whereas SL was significantly linked to $E E(r=0.475, p<0.001)$. Positive links were observed between EE and ER $(r=0.437, p<0.001)$ and between EE and ES $(\mathrm{r}=0.530, \mathrm{p}<0.001)$. All correlation values were below the cut-off of 0.70 .

Table 3. The Mean, Standard Deviations and Correlations

\begin{tabular}{l|c|c|c|c|c|c}
\hline & Mean & SD & 1 & 2 & 3 & 4 \\
\hline 1.Servant Leadership & 3.88 & .759 & - & & & \\
\hline 2.Employee Retention & 3.71 & .475 & $.503^{* *}$ & - & & \\
\hline 3.Employee Satisfaction & 4.05 & .769 & $.538^{* *}$ & $.461^{* *}$ & - & - \\
\hline Employee Engagement & 5.71 & .934 & $.475^{* *}$ & $.437 * *$ & $.520 * *$ & $.425^{* *}$ \\
\hline
\end{tabular}

Note: $\mathrm{SD}=$ Standard deviation. $* p<0.05 ; * * p<0.01$

\subsection{Structural Equation Model}

As mentioned previously, the current study utilized SEM to examine the hypotheses. The AMOS modification index results suggested linkages among the nine observed variables as shown in diagram 2. Based on the CFA results, eight items were deleted: one from ES, two 


\section{Macrothink}

from ER, and five from EE.

The four-factor measurement model revealed an acceptable data in the model analysis as following $\left(\chi^{2}=986.857, d f=478, \chi^{2} / \mathrm{df}=2.00, \mathrm{CFI}=0.900, \mathrm{RMSEA}=0.066\right)$. The $\chi^{2} / \mathrm{df}$ value of 2.00 is less than three, indicating an acceptable fit. In addition, CFI was 0.900, which is greater than 0.90; values close to one state a good fit. Finally, the value of RMSEA is less than 0.08 , indicating an acceptable fit as well.

Table 4 presents the standardized estimates (Std.Est), standard errors (S.E), and significance levels $(p)$. Hypotheses $H 1 a$ and $H 1 b$, which proposed that SL positively affects ES and ER, are significantly supported by path coefficients of $\beta=0.400(p<0.001)$ and $\beta=0.600(p<0.001)$, respectively. SL also positively affected $\mathrm{EE}(\beta=0.380, p<0.001)$, supporting $H 2$

EE was remarkably correlated with both $\mathrm{ES}(\beta=0.120, p<0.007)$ and $\mathrm{ER}(\beta=0.130, p<0.040)$. Therefore, $H 3 a$ and $H 3 b$ are supported.

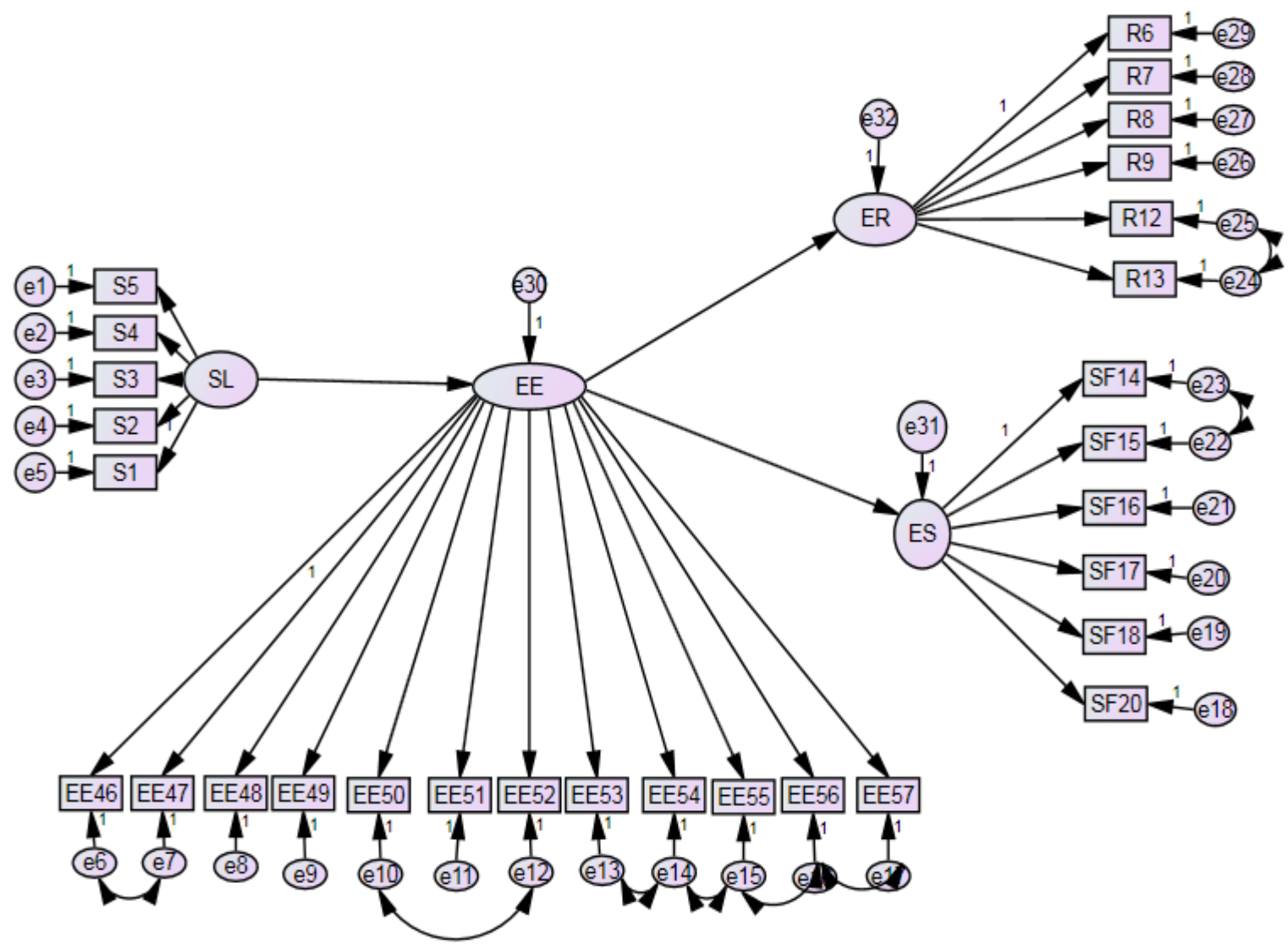

Diagram 2. Confirmatory Factor Model 


\section{Ml Macrothink}

International Journal of Human Resource Studies

ISSN 2162-3058

2019, Vol. 9, No. 3

Table 4. Results of SEM Hypotheses

\begin{tabular}{l|c|c|c|c|c}
\hline Hypotheses Testing & Std.Est & S.E & CR & P & Results \\
\hline H1a:Servant leadership $\rightarrow$ Employee Satisfaction & 0.400 & 0.042 & 5.22 & 0.001 & Supported \\
\hline H1b:Servant leadership $\rightarrow$ Employee Retention & 0.600 & 0.064 & 8.12 & 0.001 & Supported \\
\hline H2: Servant leadership $\rightarrow$ Employee Engagement & .380 & 0.050 & 5.15 & 0.001 & Supported \\
\hline $\begin{array}{l}\text { H3a:Employee Engagement } \rightarrow \text { Employee } \\
\text { Satisfaction }\end{array}$ & 0.120 & 0.064 & 2.70 & 0.007 & Supported \\
$\begin{array}{l}\text { H3b:Employee Engagement } \rightarrow \text { Employee } \\
\text { Retention }\end{array}$ & 0.130 & .090 & 2.01 & 0.040 & Supported \\
\hline
\end{tabular}

Note: Std. Est $=$ Standardized estimate, S.E $=$ Standard Error, C.R $=$ Critical Ratio.

Table 5 provides path estimates of the direct effect models. The results show that EE entered the model; the impact of SL on ES was reduced from Std.Est. $=0.39$ ( $\mathrm{p}=0.001)$ to Std.Est. $=0.32(\mathrm{p}=0.001)$, and the effect of SL on ER was reduced from Std.Est. $=0.54(\mathrm{p}=0.001)$ to Std.Est. $=0.50(\mathrm{p}=0.001)$. Thus, EE plays a partial mediator role, and $\mathrm{H} 4 \mathrm{a}$ and $\mathrm{H} 4 \mathrm{~b}$ are supported.

Table 5. Path Estimates of Direct Effect Models

\begin{tabular}{l|l|l}
\hline & \multicolumn{1}{|c|}{$\begin{array}{c}\text { Standardized regression } \\
\text { weights }\end{array}$} & $P$ \\
\hline $\begin{array}{l}\text { Direct effect without } \\
\text { mediation }\end{array}$ & & \\
\hline $\mathrm{SL} \rightarrow$ ES & 0.39 & 0.001 \\
\hline $\mathrm{SL} \rightarrow$ ER & 0.55 & 0.001 \\
\hline Direct effect with mediation & & \\
\hline $\mathrm{SL} \rightarrow$ ES & 0.32 & 0.001 \\
\hline $\mathrm{SL} \rightarrow \mathrm{ER}$ & 0.50 & 0.001 \\
\hline
\end{tabular}

\section{Discussion}

In the light of the data analysis, the current study provided critical contributions to the literature, in the domain of airline. Firstly, a positive link between SL and EE and the relationships of SL with ES and ER as indicators of organizational performance were resulted in this research. Besides, EE played a remarkable role in developing a crucial correlation between SL and OP. Secondly, this research represented a first practical research of the airline field in the context of Jordan.

On the basis of the current study's findings, it was revealed that SL played a significant role in ES similar to Rozika et al. (2018) and McNeff and Irving (2017). The scholars asserted the positive effect of SL on ES. A positive influence of SL on ER was approved in this study, similar to the results of Hajjaj (2014), Kashyap and Rangnekar (2014), and Le Ng et al. (2016). Further, the study showed the direct impact of SL in the field of airline. This finding was comparable to Karatepe and Talebzadeh (2016) who confirmed the essential part of SL in 
improving EE at the same filed in the context of Iran. Furthermore, a significant influence of SL on EE, ES, and ER was found in the present research, similar to the findings of Brohi et al. (2018), Kaur (2018), Sepahvand et al. (2015), and Hunter et al. (2013). The authors reported that SL critically affects EE, ES, and ER. Moreover, the findings revealed that EE partially mediates the impact of HPWS and SL on ES and ER. Hence, this study is the first practical research that highlights the role of EE as a mediator of the effect of SL on ES and ER. Also, it focuses on employing the SEM to analyze the data from employees working in the sector of airline.

To conclude, the current study found that SL was positively linked with ES and ER as indicators for OP. Besides, it revealed that EE partially mediates the relationships of SL with ES and ER.

\section{Implications}

The study's findings approved the significant relationship between SL and EE and the link of SL with ES and ER as indicators of organizational performance. Also, it confirmed that EE plays a remarkable part in developing a crucial correlation between SL and OP. Therefore; the management in the airline sector should focus more on developing the style of leadership in that it contributes to increase the degree of employees' satisfaction and retention at that firm. For example, the management might provide training programs on developing the character of the leaders to be motivators and influencers for the employees. In turn, the organizations' objectives and competitive advantages in the service industry could be achieved effortlessly.

\section{Limitations and Future Research}

This research examined the mediating role of EE in the relationship of SL with the OP in the airline sector. However, there were some limitations that needed to be highlighted for future researches. First, the research focused on the employees in the mentioned sector to collect the data. Consequently, future directions might involve different types of organizations such as the field of banks, which can make the results more generalized. Second, the employee satisfaction and employee retention as individual performances were the major concern of this research. Accordingly, future researches might examine the SL impact on an additional performance such as the financial outcome.

\section{Reference}

Aguenza, B., \& Som, A. (2012). Motivational factors of employee retention and engagement in organizations. International Journal of Advances in Management and Economics, 1(6), 88-95.

Albrecht, S. (2012). The influence of job, team and organizational level resources on employee well-being, engagement, commitment and extra-role performance: Test of a model. International Journal of Manpower, Special Issue Theme: Changing Work Environments and Employee Wellbeing, 33, 840-853. https://doi.org/10.1108/01437721211268357

Barakat, S., Isabella, G., Boaventura, J. M. G., \& Mazzon, J. A. (2016). The influence of corporate social responsibility on employee satisfaction. Management Decision, 54(9), 
2325-2339. https://doi.org/10.1108/MD-05-2016-0308

Bass, B. (2000). The future of leadership in learning organizations. Journal of Leadership Studies, 7, 18-40. https://doi.org/10.1177/107179190000700302

Baykal, E., Zehir, C., \& Kole, M. (2018). Effects of servant leadership on gratitude, empowerment, innovativeness and performance: Turkey example. Journal of Economy Culture and Society, 57, 29-52. https://doi.org/10.26650/JECS390903

Bery, B., Otieno, A., Waiganjo, E., \& Njeru, A. (2015). Effect of employee engagement on organisation performance in Kenya's horticultural sector. International Journal of Business Administration, 6(2), 77-85. https://doi.org/10.5430/ijba.v6n2p77

Brohi, N., Jantan, A., Qureshi, M., Bin, J. A., Bin, A., \& Bin, A. H. K. (2018). The impact of servant leadership on employees attitudinal and behavioral outcomes. Cogent Business \& Management, 5, 1-17. https://doi.org/10.1080/23311975.2018.1542652

Carter, D., \& Baghurst, T. (2014). The influence of servant leadership on restaurant employee

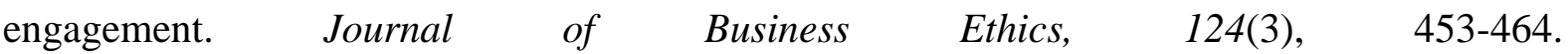
https://doi.org/10.1007/s10551-013-1882-0

Coetzer, M., Bussin, M., \& Geldenhuys, M. (2017). Servant leadership and work-related wellbeing in a construction company. SA Journal of Industrial Psychology, 43(1), 1-10. http://dx.doi.org/10.4102/sajip.v43i0.1478

Das, B., \& Baruah, M. (2013). Employee retention: A review of literature. Journal of Business and Management, 14(2), 8-16. https://doi.org/10.9790/487X-1420816

De Clercq, D., Bouckenooghe, D., Raja, U., \& Matsyborska, G. (2014). Servant leadership and work engagement: The contingency effects of leader-follower social capital. Human Resource Development Quarterly, 25(2), 183- 212. https://doi.org/10.1002/hrdq.21185

De Waal, A., \& Sivro, M. (2012). The relation between servant leadership, organizational performance, and the high-performance organization framework. Journal of Leadership \& Organizational Studies, 19(2), 173-190. https://doi.org/10.1177/1548051812439892

Devi, S. (2017). Impact of employee engagement on organizational performance: A study of select private sector banks. International Journal of Commerce and Management Research, 10-13.

Fornell, C., \& Larcker, D. (1981). Evaluating structural equation models with unobservable variables and measurement error. Journal of marketing research, 39-50. https://doi.org/10.1177/002224378101800104

Hair, J., Black, W., Babin, B., \& Anderson, R. (2010). Advanced diagnostics for multiple regression: A supplement to multivariate data analysis.

Hajjaj, K. (2014). Relationship between servant leadership style and intent to stay among the employees in the municipality of Gaza. International Journal of Business and Social Science, 5(7), 95-101. 


\section{Mll Macrothink}

International Journal of Human Resource Studies

ISSN 2162-3058 2019, Vol. 9, No. 3

Hao, M., \& Yazdanifard, R. (2015). How effective leadership can facilitate change in organizations through improvement and innovation. Global Journal of Management And Business Research, 15(9), 1-5.

Hunter, E., Neubert, M., Perry, S., Witt, L., Penney, L., \& Weinberger, E. (2013). Servant leaders inspire servant followers: Antecedents and outcomes for employees and the organization. The Leadership Quarterly, 24(2), 316-331. https://doi.org/10.1016/j.leaqua.2012.12.001

İkinci, S. (2014). Organizational change: Importance of leadership style and training. $\begin{array}{llll}\text { Management and } \quad \text { Organizational } & \text { Studies, } & 1(2), & 128 .\end{array}$ https://doi.org/10.5430/mos.v1n2p122

Jones, D. (2012). Does servant leadership lead to greater customer focus and employee satisfaction. Business Studies Journal, 4(2), 22-33.

Karatepe, O. (2013). High-performance work practices and hotel employee performance: The mediation of work engagement. International Journal of Hospitality Management, 32, 132-140. https://doi.org/10.1016/j.ijhm.2012.05.003

Karatepe, O. M., \& Talebzadeh, N. (2016). An empirical investigation of psychological capital among flight attendants. Journal of Air Transport Management, 55, 193-202. https://doi.org/10.1016/j.jairtraman.2016.06.001

Karatepe, O., \& Aga, M. (2016). The effects of organization mission fulfillment and perceived organizational support on job performance: The mediating role of work engagement. International Journal of Bank Marketing, 34(3), 368- 387. https://doi.org/10.1108/IJBM-12-2014-0171

Kashyap, V., \& Rangnekar, S. (2014). The moderating role of servant leadership: Investigating the relationships among employer brand perception and perceived employee retention. Review of HRM, 3, 105-118. http://dx.doi.org/10.2139/ssrn.2429711

Kaur, P. (2018). Mediator analysis of job satisfaction: Relationship between servant leadership and employee engagement. Metamorphosis, 17(2), 1-10. https://doi.org/10.1177/0972622518804025

Kazimoto, P. (2016). Employee engagement and organizational performance of retails enterprises. American Journal of Industrial and Business Management, 6(04), 516-525. https://doi.org/10.4236/ajibm.2016.64047

Kline, R. (2015). Principles and practices of structural equation model ( $4^{\text {th }}$ ed.) New york: the Guilford Press

Kundu, S. C., \& Lata, K. (2017). Effects of supportive work environment on employee retention: Mediating role of organizational engagement. International Journal of Organizational Analysis, 25(4), 703-722. https://doi.org/10.1108/IJOA-12-2016-1100

Le Ng, X., Choi, S., \& Soehod, K. (2016). The effects of servant leadership on employee's job 
$\begin{array}{lllll}\text { withdrawal intention. Asian Social } & \text { Science, } & \text { 12(2), }\end{array}$ https://doi.org/10.5539/ass.v12n2p99

Lisbijanto, B., \& Budiyanto. (2014). Influence of servant leadership on organization performance through job satisfaction in employees' cooperatives Surabaya. International Journal of Business and Management Invention, 3(4), 1-6.

McCann, J. T., Graves, D., \& Cox, L. (2014). Servant leadership, employee satisfaction, and organizational performance in rural community hospitals. International journal of Business and management, 9(10), 28-38. https://doi.org/10.5539/ijbm.v9n10p28

McNeff, M., \& Irving, J. (2017). Job satisfaction and the priority of valuing people: A case study of servant leadership practice in a network of family-owned companies. SAGE Open, 7(1), 1-8. https://doi.org/10.1177/2158244016686813

Myilswamy, N., \& Gayatri, R. (2014). A Study on employee engagement: Role of employee engagement in organizational effectiveness. International Journal of Innovative Science, Engineering \& Technology, 1(6), 331-333.

Nunnally, J. C., \& Bernstein, I. H. (1994). Validity. Psychometric theory, 3, 99-132.

Olesia, W., Namusonge, G., \& Iravo, M. (2013). Role of servant leadership on organizational commitment: An exploratory survey of state corporations in Kenya. International Journal of Humanities and Social Science, 3(13), 85-94.

Ongel, E. (2014). The relationship between employee engagement and organisational performance: Implementations of organizations. The International Journal of Social Sciences, 25(1), 1-10.

Otero-Neira, C., Varela-Neira, C., \& Bande, B. (2016). Supervisory servant leadership and employee's work role performance: A multilevel mediation model. Leadership \& Organization Development Journal, 37(7), 860-881. https://doi.org/10.1108/LODJ-11-2014-0230

Peterson, S., Galvin, B., \& Lange, D. (2012). CEO servant leadership: Exploring executive characteristics and firm performance. Personnel Psychology, 65(3), 565-596. https://doi.org/10.1111/j.1744-6570.2012.01253.x

Pillay, E., \& Singh, S. (2018). The impact of employee engagement on organisational performance - a case of an Insurance Brokerage company in Gauteng. Journal of Business and Management, 20(6), 66-76

Rozika, W., Dharma, S., \& Sitorus, T. (2018). Servant leadership, personnel's job satisfaction: The role of organizational culture and human resources practices. Academic Journal of Economic Studies, 4(2), 120-137.

Schaufeli, W. B., Bakker, A. B., \& Salanova, M. (2006). The measurement of work engagement with a short questionnaire: A cross-national study. Educational and psychological measurement, 66(4), 701-716. https://doi.org/10.1177/0013164405282471 


\section{Macrothink}

International Journal of Human Resource Studies

ISSN 2162-3058

2019, Vol. 9, No. 3

Schaufeli, W., \& Salanova, M. (2008). Enhancing work engagement through the management of human resources'. In, K. Näswall, M. Sverke and J. Hellgren (Eds.), The individual in the changing working life, Cambridge: Cambridge University Press, 2008, 380-404. https://doi.org/10.1017/CBO9780511490064.018

Sendawula, K., Nakyejwe, K. S., Bananuka, J., \& Najjemba, M. G. (2018). Training, employee engagement and employee performance: Evidence from Uganda's health sector. Cogent Business \& Management, 5, 1-12. https://doi.org/10.1080/23311975.2018.1470891

Sepahvand, R., Pirzad, A., \& Rastipour, M. (2015). Exploring servant leadership effects on employees satisfaction from work. International Journal of Asian Social Science, 5(1), 45-51. https://doi.org/10.18488/journal.1/2015.5.1/1.1.45.51

Spears, L. (2010). Character and servant leadership: Ten characteristics of effective, caring leaders. The Journal of Virtues \& Leadership, 1(1), 25-30.

Tischler, L., Giambatista, R., McKeage, R., \& McCormick, D. (2016). Servant leadership and its relationships with core self-evaluation and job satisfaction. The Journal of Values-Based Leadership, 9(1), 1-20. http://scholar.valpo.edu/jvbl/vol9/iss1/8

Van Dierendonck, D., \& Nuijten, I. (2011). The servant leadership survey: Development and validation of a multidimensional measure. Journal of business and psychology, 26(3), 249-267. https://doi.org/10.1007/s10869-010-9194-1

Wong, P., Davey, D., \& Church, F. (2007). Best practices in servant leadership. Servant Leadership Research Roundtable, School of Global Leadership and Entrepreneurship, Regent University, 7(1), 1-15.

Yalabik, Z., Popaitoon, P., Chowne, J., \& Rayton, B. (2013). Work engagement as a mediator between employee attitudes and outcomes. The International Journal of Human Resource Management, 24(14), 2799-2823. https://doi.org/10.1080/09585192.2013.763844

Young, H., Glerum, D., Wang, W., \& Joseph, D. (2018). Who are the most engaged at work? A meta-analysis of personality and employee engagement. Journal of Organizational Behavior, 39, 1330-1346. https://doi.org/10.1002/job.2303

\section{Copyright Disclaimer}

Copyright for this article is retained by the author(s), with first publication rights granted to the journal.

This is an open-access article distributed under the terms and conditions of the Creative Commons Attribution license (http://creativecommons.org/licenses/by/4.0/). 